\section{Cemento-Ossifying Fibroma Presenting as a Posterior Fossa Mass Lesion}

\author{
Arka Cukurda Kitle Lezyonu Etkisi \\ Yapan, Sementleșme ve Kemikleșme \\ Gösteren Fibroma Olgusu
}

\begin{abstract}
Cemento-ossifying fibromas are benign lesions of the jaw, which arise from the periodontal membrane. Histopathologically these are composed of fibrous tissues with calcified structures resembling bone and cementum. Surgical resection is the treatment of choice. They have rarely been reported in the ethmoid sinus, maxillary sinus and sphenoid sinus Mastoid bone is an extremely rare site of such tumors. Only one case of cemento-ossifying fibroma of petromastoid bone has been reported before. We present a case of cementoossifying fibroma involving the petromastoid bone, with the large intracranial component causing compression on the cerebellum. This unique case may provide insight into the etiopathogenesis of these tumors.
\end{abstract}

KEYWORDS: Cemento-ossifying fibroma, Petromastoid bone, Cerebellar signs

\section{ÖZ}

Periodontal membrandan gelişen, sementleşme ve kemikleşme gösteren fibromalar iyi huylu lezyonlardır. Histopatolojik olarak kalsifiye olmuş fibröz dokular, kemik ve semente benzerler. Cerrahi olarak çıkarılması tedavinin asıl şeklidir. Bu tip lezyonlar; maksiler sinüs, ethmoid sinüs ve sfenoid sinüsde nadir, mastoid kemikte ise çok daha az sıklıkta olarak rapor edilmiştir. Literatürde petromastoid bölgede sementleşme ve kemikleşme gösteren bir fibrom vakası bulunmaktadır. Bu yazıda petromastoid bölgeye yerleşmiş ve kafa içine doğru büyüyerek serebelluma bası yapan, sementleşme ve kemikleşme gösteren fibroma olgusu sunulmaktadır. Emsali olmayan bu vaka bu tip tümörlerin etiyopatogenezinin aydınlatılmasına katkıda bulunabilir.

ANAHTAR SÖZCÜKLER: Kemikleşme, Sementleşme, Fibroma, Kitle lezyonu, Petromastoid kemik, Serebellar bulgular

\section{Ritesh KANSAL ${ }^{1}$ \\ Arpit SHARMA ${ }^{2}$ \\ Ninad GAIKWAD \\ Amit MAHORE ${ }^{4}$}

Atul GOEL ${ }^{5}$
1,4,5 Department of Neurosurgery, King Edward Memorial Hospital, Parel, Mumbai, INDIA
2,3 Department of Otolaryngology, King Edward Memorial Hospital, Parel, Mumbai, INDIA

Received : 01.07.2009

Accepted : 20.07.2009

Correspondence address: Ritesh KANSAL

Department of Neurosurgery, King Edward Memorial Hospital, Seth G.S.Medical College, Parel, Mumbai 400 012, INDIA Phone : +9122 24129884 Fax : +91 2224143435

E-mail : drkansal@yahoo.co.in 


\section{INTRODUCTION}

Cemento-ossifying tumors are tumors of the mandible, in the molar and premolar areas. They have rarely been reported in the ethmoid sinus (4), maxillary sinus and sphenoid sinus (3). Only one case of cemento-ossifying fibroma involving petromastoid bone has been reported before (2). This is the first case of a cemento-ossifying fibroma involving the mastoid bone with intracranial extension, causing compression of cerebellum and presenting with cerebellar signs.

\section{CASE REPORT}

A 40-year-old man presented with intermittent episodes of tinnitus for fifteen years which he had ignored. In the last year, he had started noticing progressive decreased hearing in the right ear and difficulty in walking with a tendency to fall towards the right side. Computerized tomography (C.T. scan) revealed an expansile lesion of the right petromastoid bone with destruction of the bone (Figure 1). M.R.I Brain showed a contrast-enhancing mass involving the right petromastoid bone with extradural extension compressing the cerebellar hemisphere (Figure 2). A decision was made for right petromastoidectomy and excision of tumor. A right retroauricular linear incision $6 \mathrm{~cm}$ long was

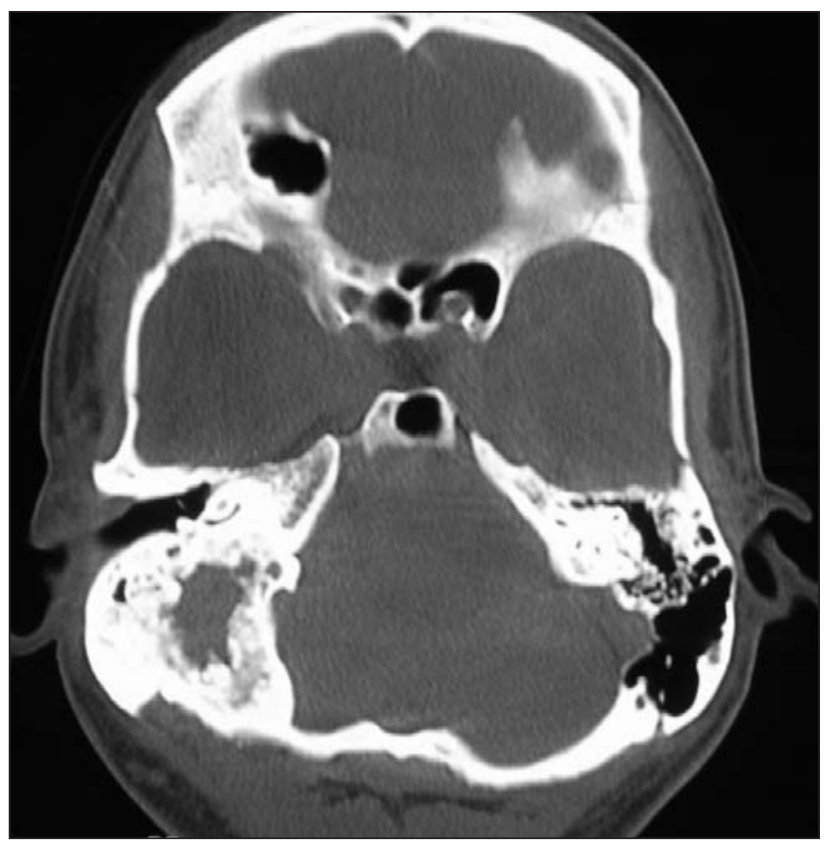

Figure 1: Computerized tomography (C.T. scan) showing expansile lesion of the right petromastoid bone with destruction of the bone. performed the muscles separated in the subperiosteal plane to expose the right mastoid process and right occipital bone. The right mastoid process was drilled. The tumor was firm to bony, destroying the mastoid bone with extradural extension. The tumor was excised until the transverse and sigmoid sinuses were exposed. The tumor was entirely extradural. Near total excision of the lesion was achieved. Histopathological evaluation of the specimen showed intense fibroblastic proliferation with; cementum and bony

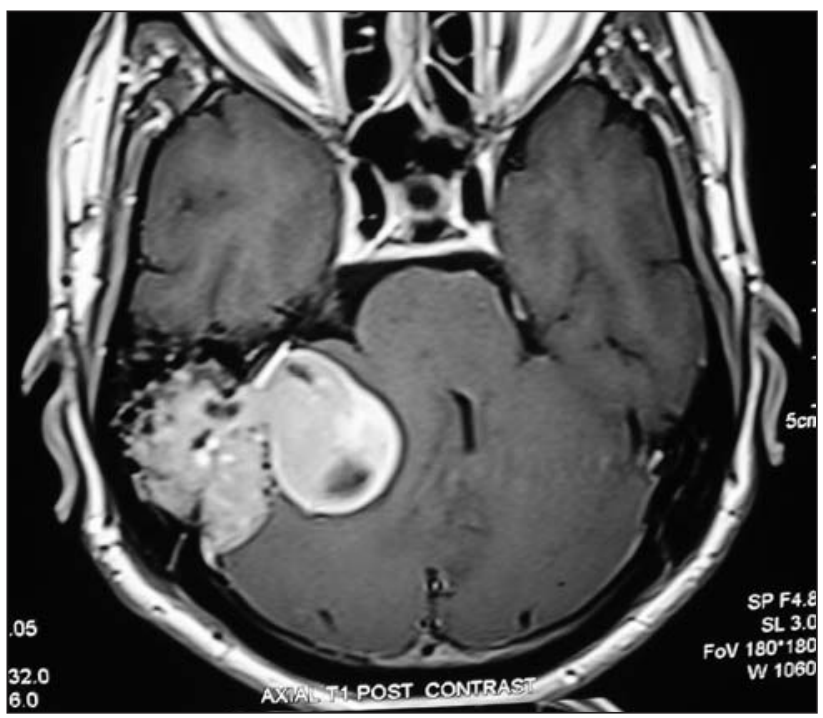

Figure 2: M.R.I Brain showed contrast enhancing mass involving the right petromastoid bone with extradural extension compressing the cerebellar hemisphere.

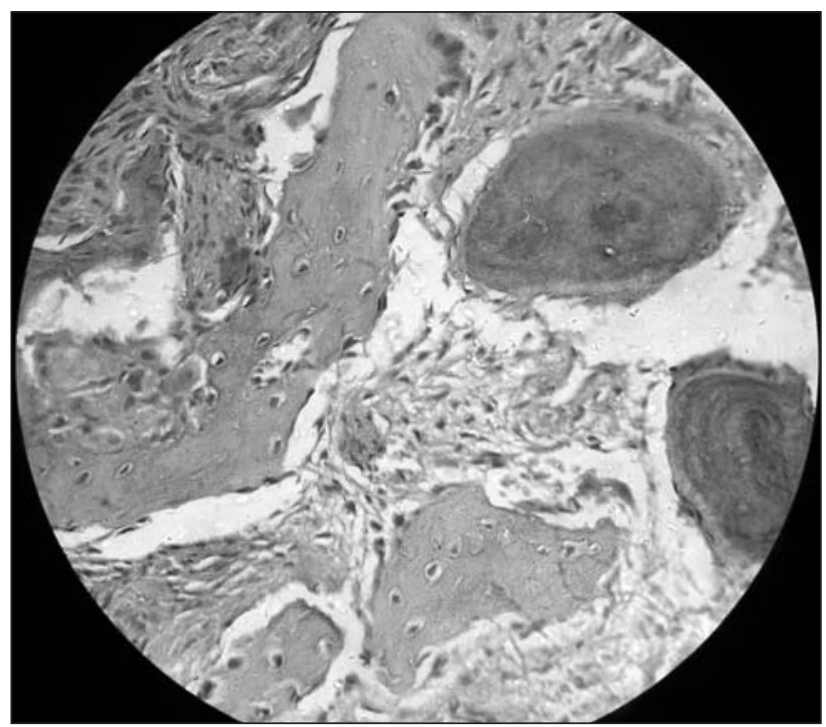

Figure 3: Histopathological evaluation of the specimen showed fibroblastic proliferation with psammoma-like masses resembling cement and lamellar bone with osteoblastic rimming. 
trabeculae, thus confirming the lesion to be cementoossifying fibroma (Figure 3). Postoperatively the patient's gait ataxia improved and he and had no additional neurological deficit.

\section{DISCUSSION}

Cemento-ossifying fibroma is a fibro-osseous lesion that arises from the periodontal membrane (6). The periodontal membrane is a layer of fibrous connective tissue surrounding the roots of teeth. It contains multipotential cells that are capable of forming cementum, lamellar bone, and fibrous tissue $(1,5)$. This explains the common location of these tumors in the mandible in molar and premolar areas. Their rare occurrence in the ethmoid may be explained embryologically by incomplete migration of mesenchyme and its differentiation into periodontal membrane (7). The occurrence in the petromastoid area has been explained by ectopic periodontal membrane differentiated from primitive mesenchymal cells in the petrous bone (2).

Trauma is commonly hypothesized to be the initiating feature of these lesions. This is commonly described in lesions in the jaw. Whiplash injury was identified as the initiating factor in the other reported cemento-ossifying lesion of the petromastoid bone (2). This patient has a history of minor trauma to head in childhood.

A close histogenetic relationship exists between the central cemento-ossifying fibroma and the central ossifying fibroma. The only difference between the two is that in cemento-ossifying fibroma there is cementum formation along with bony trabeculae while this cementum is not seen in ossifying fibroma. Cemento-ossifying fibroma is a slow-growing lesion composed of cellular fibroblastic tissue containing masses of cementumlike tissue. In addition, varying amounts of bony trabeculae are interspersed within the lesion, giving it its characteristic features (8). The presence or absence of woven and lamellar bone in histopathological section is used to differentiate the cemento-ossifying fibroma from the other fibroosseous lesions (9). These lesions need to be differentiated from fibrous dysplasia. In uncomplicated cases, fibrous dysplasia contains no lamellar bone but, rather, has arrested woven bone. On the other hand cemento-ossifying fibroma and ossifying fibroma contain woven bone and are often rimmed by osteoblasts that have laid down layers of lamellar bone. Additionally cemento-ossifying fibroma have areas of cementum, appearing as psammoma bodies embedded in a benign fibrous stroma. Spiet et al. (12) supported Reed's (9) classification and stated that the predominant pattern of bone architecture is usually apparent and allows one to differentiate between the two types of lesions.

Cemento-ossifying fibromas are mostly reported in middle age group, between $30-40$ years. This is compatible with our patient's age of 40 years (10). These tumors are generally considered to be slow growing tumors. This is also proven by the 15 year long presenting history of our patient. Previously reported case of petromastoid cemento-ossifying fibroma had presented with tinnitus and hearing loss (2). This patient had a history of tinnitus for fifteen years and describes imbalance on walking for the last year. Cemento-ossifying fibroma with a large intra cranial component in posterior fossa and presenting with cerebellar symptoms has not been described before. Management of these lesions is by total excision. The prognosis is known to be fair, and recurrence after surgical removal seems to be unusual. Radiotherapy is contraindicated because of its radio resistance and post-radiation complications (11).

\section{CONCLUSION}

Cemento-ossifying fibromas are uncommon tumors, outside the jaw. Only one case involving the petromastoid bone has been reported before. We present an interesting case of cemento-ossifying tumor of the petromastoid bone with cerebellar symptoms. This case may provide significant insight into the etiopathogenesis of this rare tumor.

\section{REFERENCES}

1. Bertrand B, Eloy P, Cornelis JP, Gosseye S, Clotuche J, Gilliard $C$ : Juvenile aggressive cement-ossifying fibroma: Case report and review of the literature. Laryngoscope 103:1385-90, 1993

2. Brademann G, Werner JA, Janig U, Mehdorn HM, Rudert H: Cemento-ossifying fibroma of the petromastoid region. Case report and review of the literature. J Laryngol Otol 111:152155, 1997

3. Cheng C; Takahashi H; Yao K; Nakayama M; Makoshi T; Nagai $\mathrm{H}$; Okamoto $\mathrm{M}$ : Cemento-ossifying fibroma of maxillary and sphenoid sinuses: Case report and literature Review. Acta Oto-Laryngologica, 118-122, 2002

4. Fujimoto $\mathrm{Y}$, Katoh M, Miyata M, Kawai T, Saito K, Morita M : Cystic cemento-ossifying fibroma of the ethmoidal cells (A case report). J Laryngol Otol 101:946-952,1987 
5. Hamner JE 3 rd, Lightbody PM, Ketcham AS, Swerdlow H: Cemento-ossifying fibroma of the maxilla. Oral Surg Oral Med Oral Pathol 26:579-87,1968

6. Huebner GR, Brenneise CV, Ballenger J: Central ossifying fibroma of the anterior Maxilla: Report of case. J Am Dent Assoc 116:507-10,1988

7. Krausen A, Gulmen S, Zogrofakis G: Cementomas - 2. Aggressive cemento-ossifying fibroma of the ethmoid region. Archives of otolaryngology 103:371-373,1977

8. Kuta AJ, Worley CM, Kaugars GE: Central Cemento-ossifying fibroma of the Maxillary sinus: A review of six cases. Am J Neuroradiol 16:1282-6, 1995

9. Reed RJ: Fibrous dysplasia of bone: A review of 25 cases. Arch Pathol 75:480-95,1963
10. Sanchis JM, PenarrochaM, Balaguer JM, Camacho F : Fibroma cemento-osificane mandibular: Presentacion de dos casos y revision de la literature. Med Oral 9:69-73,2004

11. So Lyung Jung, Kyu Ho Choia, Young Ha Parka, Hyun Chul Songa, Mi Seon Kwona: Cemento-Ossifying Fibroma Presenting as a Mass of the Parapharyngeal and Masticator Space. American Journal of Neuroradiology 20:1744-1746, 1999

12. Spiet HJ, Dorfman HD, Fetchner RE, Ackerman LV: Tumors of bone and cartilage in atlas of tumar pathology. Armed Forces Institute of Pathology section II; face V, 1971 